\title{
IMPROVING STUDENTS' WRITING ABILITY \\ IN REPORT TEXT THROUGH CLUSTERING TECHNIQUE AT GRADE XI SMAN 1 SIABU
}

\author{
By: Rayendriani Fahmei Lubis, M.Ag., Fitri Rayani Siregar, M.Hum., \\ and Yeni Riska
}

\begin{abstract}
ABSTRAK
Penelitian ini berbicara tentang peningkatan kemampuan menulis siswa dalam teks laporan melalui teknik clustering pada kelas XI SMAN 1 Siabu, masalah siswa dalam kemampuan menulis adalah siswa tidak memiliki gagasan untuk menulis, siswa tidak dapat mengembangkan gagasan untuk menulis, siswa tidak tertarik untuk menulis bahasa Inggris dan guru bahasa inggris tidak memiliki teknik yang tepat. Tujuan dari penelitian ini untuk mendeskripsikan prestasi belajar siswa dalam menulis teks laporan dan untuk mengetahui faktor-faktor yang mempengaruhi penulisan laporan teks siswa dengan teknik clustering pada kelas XI SMAN 1 Siabu. Metode penelitian adalah tindakan kelas dengan menerapkan Kemmis dan Mc Taggart yang dirancang yang terdiri dari empat tahap. Itu adalah rencana, tindakan, amati, dan renungkan. Selain itu, untuk mengatasi masalah penulisan teks tulisan, peneliti menerapkan teknik clustering. Peserta penelitian adalah seluruh siswa kelas XI IPA3 SMAN 1 Siabu yang terdiri 28 siswa. Instrumen pengumpulan data adalah tes dan observasi. Teknik analisis data adalah mean score dan t-test. Berdasarkan hasil penelitian, menunjukkan peningkatan kemampuan menulis siswa dalam teks laporan melalui penerapan teknik clustering. Skor rata-rata siswa menunjukkan peningkatan penulisan teks laporan siswa. Hasil uji pertama pada siklus I adalah 58,92 (25\%) dan uji kedua pada siklus II adalah 83,28 (89,28\%). Skor rata-rata siklus kedua lebih tinggi dari siklus pertama. Penerapan teknik clustering dapat meningkatkan kemampuan menulis siswa dalam teks laporan pada kelas XI IPA 3 SMAN 1 Siabu, artinya hipotesis dapat diterima.
\end{abstract}

Key words: Writing Ability, Report Text and Clustering Technique

\section{A. Introduction}

Writing is one of four language skills that is very important to learn. Writing is powerful process for describing, synthesizing, analyzing, interpreting, and communicating experience. As a result is part of the important language teaching 
and learning. Many people feel that writing is difficult, First, writing needed time to describe for anything to write. Second, writing can be edited and revised but too many revise make them lazy and let it. It will be possible to do mistake in writing especially grammar and vocabulary.

Writing report text is a writing activity that purposes to tell somebody about something, especially something that you have experience. Writing reports are written about living things like plants and animals. From explanation above, the writer concluded that report text is necessary for everybody in variety of purposes and needs. So, if the students want described the things, peoples, and animals, they are able to understanding of report text. Besides that, based on writers observation that students ability in writing report text is still low, they did not have many vocabularies to develop idea to write report text, they are also can't determine generic structure of the text. They have difficulties to build and develop their ideas and they could not be able to write and communicate English well. Finally The English teacher always ask students translated the text. ${ }^{1}$ Then, the writer would like to propose a technique which is called clustering technique.

This technique is good and easy. It is effective to be used in teaching by the teacher. At least some reasons are available as background of the choice. First, clustering technique makes visual map to produce a topic related to each other. Second, clustering technique will stimulus students' ideas, also they can make a good paragraph in every types of genre. Third, clustering technique can help students to think a visual way, and last, clustering technique is another strategy that can generate materials for paper. Based on the explanation above, the researcher is interested to conduct a Classroom Action Research, which purposes to improve students writing ability through clustering technique at grade XI SMAN 1 Siabu.

\section{B. The Objectives of the Research}

Based on the research question above, there were two objectives of the research, as follow:

1. To describe improvement of the students achievement in writing report text through clustering technique at grade XI SMAN 1 Siabu.

\footnotetext{
${ }^{1}$ Santri Safitri, Private Interview to the Students of SMAN 1 Siabu. ( Siabu: SMAN 1,September $02^{\text {th }}, 2016$ on $\left.09 \mathrm{pm}\right)$.
} 
2. To identify the factors which influence of students writing ability in report text through clustering technique at grade XI SMAN 1 Siabu.

\section{The Concepts of Key Terms}

To avoid vagueness and misunderstanding between the researches and the reader, there are researches states the terminologies are:

1. Improving means become or make better. ${ }^{2}$ Improving was a process of becoming or making students' writing ability better through several cycles which is a change that improves students' writing ability by using a certain technique. Improving is a verb that making something better. So, improving is going through better work to achieve something.

2. Students are person who is studying at college or university. ${ }^{3}$ Students is a person who attends a school, college, or University and studies something. The research assumed that a student is person who learns on the elementary, junior, and senior high school for both formal and informal education.

3. Writing according to Hornby said "Writing is written works of an author or persons hand writing". ${ }^{4}$ Then, according to David Nunan, "Writing is both a physical and mental act". 5 So, it is a mental work in creating ideas to express and to organize them in paragraph or text so that the readers will be easier to understand the writer intention.

4. Ability is the mental or physical capacity, power or skill required to do. Meanwhile, ability is the fact that somebody is able to do something. ${ }^{6}$ So, ability means the power or capacity to do something well.

5. Clustering is making a visual map of the ideas. Clustering is another brainstorming activity you can use to generate ideas. Based on the definition the researches assumed that clustering is activity before writing a text by making a note in advance about the ideas that are owned and relevance of the fact that the text will be written.

${ }^{2}$ A. S. Hornby, Oxford Learners Pockets Dictionary $4^{\text {th }}$ Edition (New York: Oxford University Press, 2008), p. 222.

${ }^{3}$ Ibid., p. 441.

${ }^{4}$ A. S. Hornby, Oxford Learners $4^{\text {th }}$ Edition....p. 516.

${ }^{5}$ David Nunan, Practical English Language Teaching (USA: The Mecraw Hill Companies, 2003), p. 88.

${ }^{6}$ A. S. Hornby, Oxford Learners $4^{\text {th }}$ Edition ......., p. 2. 
6. Report Text is a kind of pare result of perception, research, observation, or study about object, animal, people or place. ${ }^{7}$ While, Report text is being used in a very specific way to refer only to text used to store information about a class of thing. Report text is a kind of genre which has the aim to inform the reader. So, Report text is a kind of text that give general information about something.

\section{Research Methodology}

\section{The Place and Schedule of the Research}

The research would be conducted at SMAN 1 Siabu that is located on Jln. Medan Padang. Kec. Siabu, Kab. Mandailing Natal. This research conducted in academic year 2016/2017 and time of this research was done on 29 April until finished.

\section{The Research Design}

This research is designed by classroom action research (CAR). According to Eriction S. Sabacan stated action research is the process by which practitioner attempt to study their problems scientifically in order to guide, correct and evaluate their decisions and actions. Action research specifically refers to a disciplined inquiry done by a teacher with the intent that the research will inform and change his or her practices in the future.

Based on Gay and Airasian classroom action research is a type of practitioner research is used to improve the practitioner's practice; action implies doing or changing something. ${ }^{8}$ Accordingly, this research is conduct which is use to improve the teacher's practice in the classroom for writing ability teaching applies by using clustering technique or changing student's prior writing ability at low competence to the better competence by its criteria.

According to Kemmis and McTaggart in Anne Burns who are major in this field, action research typically involves four broad phases in a cycle of research, namely, planning, action, observation, and reflection. ${ }^{9}$ The first cycle

\footnotetext{
${ }^{7}$ Otong Setiawan Djuhari, Genre (Bandung : Yrama Widya, 2007 ), p. 26.

${ }^{8}$ L. R. Gay \& Peter Airasian, Educational Research, (New Jersey: Prentice Hall Inc, 2000), p. 593.

${ }^{9}$ Anne Burns. Doing Action Research in English Language Teaching, (New York: Routledge, 2010), p. 8.
} 
may become a continuing or literative, spiral of cycles which recur until the action researcher has achieved a satisfactory outcome and feels it is time to stop.

In this research the writer applied two cycles. Each cycle consists of two meetings each meeting consist of 90 minutes. So, there were four meetings during research process. Each cycle consist of four steps; planning, acting, observing, and reflecting.

\section{The Participant}

The participants of this research is classroom XI IPA-3 of SMAN 1 Siabu in academic year 2016/2017 where they are totally 28 student's consisted of 7 males and 21 females. The researcher choose this class because the researcher found the problems of writing in this class, such as the students didn't have idea to write, the students couldn't develop idea to write, the students didn't have interest in writing English, the English teacher didn't have appropriate technique.

\section{The Techniques of Data Collecting}

Instruments refer to tools which use by the researcher in collecting the data. In collecting the data, the researcher using instrument of data collecting is test and observation.

a. Test

A test as a method of measuring a person's ability: knowledge or performance in given domain. ${ }^{10}$ The test is use by the researcher to find out any problem weakness regarding the students writing ability. Researcher took the writing evaluation criteria rubric as reference in the process of learning to get student's score. The test in this research is writing report paragraph by using clustering technique. The students would be testing based on the topic. The criteria of the qualification score is presented in the following table:

${ }^{10} \mathrm{H}$. Douglas Brown, Teaching by Priciples An Interactive Approach to language Pedagogy, New York: Pearson Education. Inc...2004), p.384 
Table 1

The Criteria of the Qualification Score

\begin{tabular}{|c|l|c|}
\hline No & Criteria & High Score \\
\hline 1 & Grammar & 20 \\
\hline 2 & Vocabulary & 20 \\
\hline 3 & Mechanic & 20 \\
\hline 4 & Fluency & 20 \\
\hline 5 & Form & 20 \\
\hline \multicolumn{2}{|c|}{ TOTAL SCORE } & 100 \\
\hline
\end{tabular}

b. Observation

The researcher use observation sheet type field notes to gather the data. Gay and Airasian pointed out field notes are observer's record or documenting of what the researcher has seen, hear, experience thought about during and observing session. ${ }^{11}$ Researcher collects the data from the field. In the process of observing writing, reflecting on field notes, qualitative researcher engage in a process of enveloping data analysis. The researcher observation is done by researcher directly to the location of the researcher to see the students' ability in writing report text.

\section{The Research Procedures}

The action research followed the model that was developed by cyclical AR model based on Kemmis and Mc Taggart. It is famous representation of the action research "cyclical" that contains four stages: planning, acting, observing and reflecting. In this research, the researcher applied two cycles. Every cycles consist of two meeting, and the time allocation is $2 \times 45$ minutes/ 90 minutes. Moreover, every meeting consists of four steps of classroom action research such as planning, action, observing, and reflection. Here, the explanation of activities in teaching writing through clustering technique at grade XI, especially XI IPA 3 SMA Negeri 1 Siabu.

\footnotetext{
${ }^{11}$ L. R. Gay and Peter Airasian, Educational Research, (New Jersey: Prentice Hall Inc, 2000), p.
} 593. 


\section{a. First Cycle}

\section{1) First Meeting}

a) Planning

i. Making lesson plan.

ii. Determining the lesson material is about the report text.

iii. Designing the procedure teaching writing through clustering Technique.

iv. Preparing instrument for students.

b) Action

i. Explaining the aim of the research

ii. Giving the motivation to students

iii. Giving the topic for the students.

iv. Explain about report text

v. Introducing and explain about the clustering technique

vi. Give example of clustering design of report text

vii. The teacher ask the student's to mention their favorite animal

viii. The teacher ask the student's to find out five words that can to show the description of their favorite animal

ix. Monitoring time allocation with all activity is done

x. Collecting the students result

c) Observation

i. Observing the execution of writing report text.

ii. Evaluating students by taking the score of student's writing ability based on the indicator.

d) Reflection

i. Discuss with the teacher about the action.

ii. Making any decision for next cycle.

iii. Developing another environment to be stimulated.

iv. Analyzing the data have found.

v. Clarifying the problem found in the activity whether in the case of students or teacher. 


\section{2) Second Meeting}

a) Planning

i. Design the teaching writing procedure through clustering technique.

ii. Prepare the final draft sheet for each students as a sheet where the students write back their draft as the final result of their writing.

b) Action

i. Giving the motivation to students

ii. Giving learning material to students

iii. Using the clustering technique to students in learning material.

iv. The teacher ask the students to make the first draft of clustering design that they have done

v. Helps to students to keep practicing in activity

vi. Taking student's to execute the activity to test the student's writing skill.

vii. Giving the limited time for students

viii. Monitoring time allocation with all activity is done

ix. Collecting the students result

c) Observation

i. Observing the students writing skill.

ii. Observing the students difficulties while doing the task given.

iii. Observe problems in the process of learning and giving solutions.

d) Reflection

i. Discuss with the teacher about the action

ii. Analyzing the weakness and progress when clustering technique is done to determine the next activity.

iii. Analyzing the data have found.

iv. Clarifying the problems found in the activity whether in the case of students or teacher. 


\section{b. Second Cycle}

\section{1) First Meeting}

a) Planning

i. Teacher make lesson plan more.

ii. Preparing another media that will be used in teaching learning process.

iii. Design a procedure teaching writing text through clustering technique.

b) Action

i. Preparing class and greet when open the matter.

ii. Giving learning material to students then discuss is together with the students.

iii. Show up pictures bird and butterfly in the white board.

iv. The teacher give explanation about report text appropriate based on the topic

v. Using the clustering technique to students in learning material.

vi. Giving the chance to students to write the report text by using clustering technique relate the example.

vii. The teacher improve observation in class

viii. The teacher give more effective advise.

ix. Teacher circle to watch students.

$\mathrm{x}$. Teacher also give help if there which difficult in class.

xi. Collecting the students result.

c) Observation

i. Monitoring the teaching learning by using clustering technique in teaching learning.

ii. Discussion the problem in process giving solution.

iii. Discussion about the writing text result.

d) Reflection

i. Analyzing the finding during the observation is done.

ii. Analyzing the weakness and progress when clustering technique is done determine the next activity planning. 
iii. Reflection for teaching activity and students learning result that using clustering technique.

\section{2) Second meeting}

a) Planning

i. Design the teaching writing procedure through clustering technique.

ii. Prepare the final draft sheet for each students as a sheet where the students write back their final draft as the final result of their writing.

b) Action

i. Preparing class and greet when open the matter.

ii. Giving learning material to students then discuss is together with the students.

iii. The teacher ask to students to write first draft appropriate with clustering technique in the report paragraph form

iv. The teacher improve observation in class

v. Teacher also give help if there which difficult in class

vi. The teacher give more effective advise

vii. The teacher ask to students to change their task

viii. The teacher ask the students to make note about their partner task sheet about grammar and vocabulary

ix. The teacher ask students to write the last draft

$\mathrm{x}$. Teacher ask the students to read their task

xi. Collecting the students result

c) Observation

i. Teacher monitoring the student's activity when performance begin.

ii. Discussion the problem in learning process and giving solution.

iii. Discussion about the writing text. 
d) Reflection

In this cycle, the researcher can reflect the data have found. The reflection will be gathered from the result of writing test through clustering technique.

\section{Finding}

Based on the related finding, the researcher discussed that the researcher findings had shown students' writing report text improved well. It could be proved by students' mean score and percentage. It also discussed with the theory that relate to the clustering technique. In this case, the theory which has been discussed by the researcher was from the founder of clustering technique, According Alice and Oshima, Clustering technique is a another prewriting technique you can to get ideas. ${ }^{12}$ The theory has been proved where the students were so enthusiastic to follow the English lesson because this technique is made students work to write paragraph report text well, this technique ensures that each students knows the answer to problems or questions asked by the teacher.

There was a thesis that researcher used as related finding. The research had been done in English educational department, Jakarta, 2015. Her name is Tita Nurul Fajriyani. Her research was about 'Improving Students' Writing Ability Through Clustering Tehnique". ${ }^{13}$ She told that clustering technique could improve students' writing ability. In this study, it had found that the improvement of students' achievement by using clustering technique. The mean score in cycle 1 was 10.58 and in cycle 2 was 11.71 . So, cycle 2 was bigger than cycle 1 .

Based on the explanation above, the researcher found the similarity with the others researcher and the theory which is related to clustering technique. His name is Ismatul Maula, his research was about " The effectiveness of clustering technique in teaching of narrative text at the tenth grade students of SMA PGRI 56 ciputat ". ${ }^{14}$ It was based on the data in the pre test was 6.69 and in the post test was 7.84. It can be concluded that the researcher had been success in doing the research.

\footnotetext{
${ }^{12}$ Alice Oshima, and Ann Hogue, Introduction to Academic Writing., ....p. 74.

${ }^{13}$ Tita Nurul Fajriyani, Improving Students Writing .......

${ }^{14}$ Ismatul Maula, The Effectiveness of Clustering Technique.
} 
Finally, a script of Abd Salam. ${ }^{15}$ The kind of the research is Classroom action research. The researcher found that Clustering Technique is a good method in improving writing ability Then, the conclusion are: the students achievement in writing is 72,4 .

From the review of related finding above, the researcher also found the result that, clustering technique improve the students ability in writing report text at classroom XI IPA 3 SMAN 1 Siabu. The result was found during the research showed that the students enjoyed the lesson through clustering technique. The learning activity was more comfortable for the students where they could use their critical thinking while giving clustering technique when their writing report text. Finally students writing ability improved significantly, the improvement of students ability was $\mathbf{5 8 . 9 2}(\mathbf{2 5} \%$ ) in the first cycle and $\mathbf{8 3 . 2 8}(\mathbf{8 9 . 2 8} \%)$ in the second cycle.

\section{c. Conclusion}

Based on the findings of this research, the researcher conclude that :

1. Clustering technique could improve in teaching writing report skill at classroom XI IPA-3 SMAN 1 Siabu. It based on the students' writing score, the mean score in the cycle I was 58.92 (25\%) then in the cycle II was $83.28(89.28 \%)$. The students' improvement can be categorized into high motivation. Then the calculate result of $t_{o}=65.23, t_{\text {table }}$ with $\mathrm{df}=27$, level of significance in t table $5 \%$ is 40.113. It can be known that the result of $t_{o}$ is bigger than $t_{t}$, it is 65.23>40.113. Based on the result, it means that there is a significant improvement between students' writing report text through clustering technique learning process result in the first cycle and second cycle.

2. Some factors that influence student's speaking ability by using clustering technique were internal factors that were grammar, vocabulary, mechanics, fluency, and form. Meanwhile, external factors that were the students who made noisy in the classroom, the students asked for permissions, the students who slept in the classroom, the students who sat in the move, the students who felt bored of this lessons. The solutions of the problems are; researcher motivated them, researcher teaching mostly about indicators writing.

\footnotetext{
${ }^{15}$ Abd Salam, using clustering technique.......
} 


\section{REFERENCES}

Axelord, Rise B and Charles R. Cooper, Concise Guide to writing, New York : St Martin's, 2012.

Abd, Salam, Using Clustering Technique to Improve Students Writing of Recount Text at SMPN 2 Tarumajaya, Bekasi, Script UIN Syarif Hidayatullah Jakarta, 2011. Retrieved from http://repository.uinjkt. ac.id/dspace/bitstream/ $1234 \quad 56$ 789/448/1/ABD\%20SALM.FITK.pdf on Monday 31 October 2016, at $16.20 \mathrm{pm}$.

Burns, Anne., Doing Action Research in English Language Teaching, New York: Routledge, 2010.

Brown, H. Douglas, Language Asessment: principles and Classroom Practice, New York: Pearson Education. Inc...2004.

, Teaching by Principles: An Interactive Approach to Language Pedagogy, New Jersey: Prentice Hall, 1994.

College, Skyline, The Writing Process; Prewriting, retrieved from www.skylinecollege.edu/skyenglish/4prewriting.pdf, accessed on $24^{\text {th }}$ Oct 2016.

Damayani, Disadvantages of Clustering Technique, retrieved from https://disadvantages of clustering teachnique.edu.ac.id. accessed at december $10^{\text {th }} 2016$.

Denzin, Norman K and Yvonnas. Lincoln, A Handbook of Qualitative Research, Translated by Dariyanto and Friends, Yogyakarta: Pustaka Pelajar, 2009

Fajriyani, Tita Nurul. Improving Students Writing Ability Through Clustering Technique, Script UIN Syarif Hidayatullah Jakarta, 2011. retrieved from http://repository.uinjkt.ac.id/dspace/bitstream/123456789/1721/1/102345TITA\%2 ONURUL\%2OFAJRIYANI-FITK.pdf on Monday 31 October 2016, at 16.00 pm.

Feradilla, Eramona, and Muhd. Al Hafizh, Using The Clustering Technique in Teaching Writing a Descriftive Text to Junior High School, JELT Vol. 2 No.2 Serie A. March 2104. retrieved from http://ejournal.unp.ac.id/index.php/ eramonaferadilla/jelt/issue/view/462/showToc, on Monday 31 October 2016, at $16.25 \mathrm{pm}$.

Gay, L. R. and Peter Airasian, Educational Research: Comptensies for Analysis and Application, New Jersey: Prentice Hall Inc., 2000.

Hasanah, Riski., Teknik Clustering, retrieved from Https;//cademimia.edu.ac.id. Accessed at December $10^{\text {th }} 2016$. 
Hornby, A.S.,Oxford Learners Pockets Dictionary $4^{\text {th }}$ Edition, New York: Oxford University Press, 2008.

Hughes, Arthur., Testing For Language Teacher, New York: Cambrige University Press, 1990.

Juzwiak, Chris., Stepping Stones: A Guided Approach to Writing Sentences and Paragraph, New York,: Bedford/St. Martin's, 2012.

Langan, Jhon., Exploring Writing :Sentence and Paragraphs, New York : McGrawHill Companies, Inc, 1221.

Lubis, Private Interview to the English Teacher of SMAN 1 siabu, Siabu: SMAN 1 Siabu, 2016.

Nunan, David., Practical English Language Teaching, USA: The Mecraw Hill Companies, 2003.

O’Malley. J.M. \& L.V. Pierce. Authentic Assessment For English language Learners, New York: Addison Wesley, 1996.

Oshima, Alice and Ann Hogue, Introduction to Academic Writing, USA: Person Longman, 2007.

Pardiyono, Pasti Bisa Teachning Genre Based Writing., Yogyakarta : Andi Offset, 2007.

Safitri, Santri, Private Interview to the Students of SMAN 1 Siabu. Siabu: SMAN 1 Siabu, 2016.

Setiawan, Otong Djuhari, Genre, Bandung : Yrama Widya, 2007.

Siahaan, Sanggam and Kisno Shinoda, Generic Text Structure, Yogyakarta : Graha 2008.

Surya, Luphani, Report Text, retrieved from http://suryaluphani4. blogspot.co.id/2012/12/report-text.html. Accessed on $24^{\text {th }}$ March 2017.

Tarigan, Guntur, Menulis sebagai suatu Keterampilan Berbahasa, Bandung: Angkasa, 1986

Ur, Penny, A Course in Language Teaching, USA : Cambridge University Press, 1991

Yulianto, Puguh, Report Text, retrieved from http://www.englishindo. Com /2012/03/ report-text-penjelasan-contoh.html. Accessed on $24^{\text {th }}$ Oct 2016 at $15.30 \mathrm{pm}$ 